\title{
SISTEM PENGAMBILAN KEPUTUSAN DALAM PENENTUAN KELAS JABATAN FUNGSIONAL UMUM (JFU) PEGAWAI NEGERI SIPIL (PNS) MENGGUNAKAN METODE MULTI ROUGH SET DAN FUZZIFIKASI
}

\author{
Asri Yulianti ${ }^{1}$ \\ Kementerian Agama Kabupaten Jember ${ }^{1}$ \\ Email ${ }^{1}$ : asrieys80@gmail.com
}

(Naskah masuk: 12 November 2018, diterima untuk diterbitkan: 18 Desember 2018)

\begin{abstract}
Abstrak
Seorang Pegawai Negeri Sipil (PNS) pada instansi pemerintah, dituntut harus memiliki kompetensi atau kemampuan untuk dapat melakukan pekerjaan secara efektif dan efisien sesuai dengan bidang dan lingkup pekerjaannya. Pada kenyataannya, proses penentuan kompetensi dan kelas jabatan sangat berpengaruh bagi proses penempatan Jejabat Fungsional Umum (JFU) seorang Pegawai Negeri Sipil dan karena proses tersebut selama ini masih dilakukan secara manual, maka waktu yang dibutuhkan cukup lama dan hasil yang diperoleh belum tentu akurat sesuai dengan kompetensi yang dimiliki. Pada penelitian ini, Metode Multi Rough Set digunakan dalam penentuan klasifikasi kompetensi dan kelas jabatan bagi PNS yang belum diketahui kompetensinya maupun sebagai bahan evaluasi kinerja pegawai yang telah menduduki suatu jabatan. Metode Multi Rough Set ini dilakukan dengan cara membagi data set menjadi beberapa data set dengan atribut yang sejenis. Berdasarkan penelitian yang telah dilakukan, dapat diketahui bahwa Metode Multi Rough Set sebagai metode klasifikasi yang baik (Good Classifier) dalam pengambilan keputusan klasifikasi kompetensi pegawai dalam Jabatan Fungsional Umum, karena berdasarkan hasil kurva pada Receiver Operating Characteristic (ROC) mempunyai luas daerah di bawah kurva sebesar $\mathbf{0 , 8 6 6}$, selain itu rata-rata error dari hasil klasifikasi dengan Metode Multi Rough Set yang digabungkan dengan pengambilan keputusan melalui fuzzifikasi meningkat secara signifikan dibandingkan dengan Metode Single Rough Set yaitu dari $\mathbf{2 8 , 7 5 \%}$ menjadi $\mathbf{0 \%}$ untuk hasil yang tidak terklasifikasi.
\end{abstract}

Kata kunci: Kompetensi Jabatan, Pegawai Negeri Sipil (PNS), Kelas Jabatan Fungsional Umum (JFU), Fuzzifikasi, Multi Rough Set.

\section{DECISION MAKING SYSTEM FOR DETERMINING CLASS IN GENERAL FUNCTIONAL WORKS CLASSIFICATION OF CIVIL SERVANTS USING MULTI ROUGH SET METHOD AND FUZZIFICATION}

\begin{abstract}
A Civil Servant in government agencies is required to have the competency or ability to be able to perform work effectively and efficiently in accordance with the field and scope of work. In fact, the process of determining the competency and class of works is very influential for the process of placement of General Functional Works of a Civil Servant. However, the process takes a long time because it is still done manually. Moreover, the obtained results are not necessarily accurate in accordance with the competence which is owned by the civil servants. In this study, Multi Rough Set Method is used for determining unknown civil servants competency classification and class position, or as civil servants performance evaluation. The multi Rough Set method is applied by dividing the data set into several similar attributes data sets. Based on the research that has been conducted, it can be seen that the Multi Rough Set Method is a good classifier method in decision making of employee competency classification in General Functional Work. It is because based on the Receiver Operating Characteristic (ROC) curve results, the area under the curve reaches 0.866. Besides, the average error from the results of the classification using the combination of Multi Rough Set Method and fuzzification increased significantly compared to the Single Rough Set Method which goes from 28.75\% to $0 \%$ for unclassified results.
\end{abstract}

Keywords: Job-Competency Classification; Civil Servants; Class of General Functional Works; Multi Attributes; Multi Rough Set.

\section{PENDAHULUAN}

Arah kebijakan reformasi birokrasi menurut Undang-undang nomor 5 tahun 2014 bertujuan untuk meningkatkan profesionalitas Pegawai Negeri Sipil (PNS) atau Aparatur Sipil Negara (ASN) dalam rangka meningkatkan pelayanan yang lebih baik, lebih bersih dan lebih kompeten. Proses pelaksanaan manajemen Sumber Daya Manusia (SDM) seperti proses rekrutmen, promosi, mutasi, dan rotasi pegawai seyogyanya harus seiring sejalan dengan tata 
kelola pemerintahan yang baik serta berbanding lurus dengan tingkat kompetensi dan kualifikasi yang dimiliki oleh calon pemangku jabatan.

Efektifitas kinerja individu dalam pekerjaannya yang didasari oleh karakteristik seseorang disebut sebagai kompetensi. Kompetensi yang harus dimiliki oleh seorang ASN sehingga mampu mentransformasi gaya kerja dari zona nyaman menuju zona kompetitif yaitu berupa karakteristik kemampuan, peran sosial, nilai diri, perilaku, sikap dan motif.

Pada tahun 2014-2015 peringkat Daya Saing Kompetensi Global Indonesia berdasarkan Global Competitiveness Index berada diurutan ke 34 dari 144 negara di dunia. Pada Gambar 1, menunjukkan grafik yang dikeluarkan oleh World Economic Forum, bahwa Indonesia berada diurutan kelima sesudah Singapore, Malaysia, Brunei, Thailand diatas 12 negara lainnya di South Asia and South East Asia, namun masih berada diatas India yang berada di urutan ke 60 dunia.

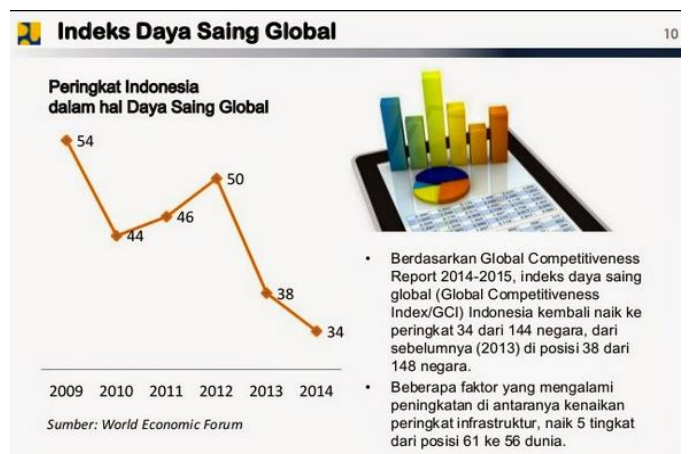

Gambar 1. Peringkat Indeks Daya Saing Global Indonesia Menurut Global Competitiveness Index 2014-2015 (Forum, 2016)

Kompetensi seorang PNS erat kaitannya dengan kemampuan yang diwujudkan dalam sikap dan perilaku, pengetahuan, keterampilan serta kecakapan, yang diperlukan untuk melaksanakan tugas pokok, fungsi, kewenangan dan tanggungjawab yang diamanatkan kepadanya. Bass (1985) berpendapat bahwa dalam kompetensi PNS dapat terpenuhi, dan dapat diupayakan melalui kompetensi transformasi seorang pemimpin, yaitu : (1). Meningkatkan kesadaran pegawai terhadap nilai dan pentingnya tugas dan pekerjaan, (2). Terarahnya fokus utama pegawai pada tujuan kelompok dan organisasi, bukan pada kepentingan pribadi, dan (3). Potensi pegawai dapat dikembangkan secara optimal.

Keputusan Kepala Badan Kepegawaian Negara Nomor 13 Tahun 2011 tanggal 28 Juni 2011 tentang Pedoman Penyusunan Standar Kompetensi Jabatan ditetapkan sebagai panduan dalam penyusunan standar kompetensi jabatan bagi setiap instansi pemerintah baik pusat maupun daerah. Standar Kompetensi Jabatan itulah yang menjadi syarat minimal kompetensi yang harus dimiliki seorang PNS dalam melaksanakan tugas pokok dan fungsi jabatan.

Dengan demikian, merupakan hal yang sangat penting bagi setiap PNS baik pejabat struktural maupun pejabat fungsional (fungsional umum maupun fungsional tertentu) harus memiliki standar kompetensi jabatan sesuai (Syam, 2015). Beraneka ragamnya nama jabatan yang akan dipangku oleh seorang PNS serta bidang atau unit dimana PNS tersebut akan ditempatkan, seharusnya disesuaikan dengan kompetensi yang dimiliki oleh PNS tersebut. Akan tetapi pada kenyataannya proses penempatan dan penentuan kelas jabatan pada PNS akibat adanya proses mutasi maupun promosi, yang terjadi selama ini, seringkali tanpa melihat kompetensi yang dimiliki oleh PNS tersebut, sehingga hal ini menyebabkan terhambatnya proses pelayanan pada bidang atau unit tersebut, yang seharusnya berjalan dengan optimal, akhirnya akan menjadi lamban. Begitu juga proses transfer knowledge dari pejabat lama kepada pejabat baru, akan membutuhkan proses yang cukup lama, hal ini juga akan memperlambat proses pelayanan di bidang lain dimana pejabat baru ditempatkan.

Metode Multi Rough Set ini didasarkan pada pendekatan Metode Rough Set. Metode dipilih karena berdasarkan beberapa referensi terdahulu, bahwa terdapat beberapa penelitian yang menggunakan metode Rough Set dalam penentuan klasifikasi, yaitu antara lain: Penelitian oleh (Fanani., 2016) yang berjudul Multi Attribute Decision Making Model Using Multi Rough Set: Case Study Classification of Anger Intensity of Javanese Woman, berdasarkan penelitian tersebut menunjukkan bahwa pengambilan keputusan menggunakan multi Rough Set dapat digunakan untuk mengurangi keputusan yang belum terklasifikasi dan dapat meningkatkan tingkat akurasi pada proses klasifikasi. Penelitian oleh (Reddy, 2011) yang berjudul Rough Set Anlaysis for Uncertain Data Classification. Dalam paper ini dijelaskan bahwa Metode Rough Set untuk menentukan nilai atribut A yang tidak diketahui melalui rules yang dihasilkan. Sedangkan menurut (Elshazly, 2012) dalam papernya yang berjudul Rough Sets And Genetic Algorithms: A Hybrid Approach To Breast Cancer Classification, dijelaskan bahwa Metode Rough Set dan Algoritma Genetika digabungkan dengan tujuan untuk melakukan proses klasifikasi Penyakit Kanker Payudara. Dari penelitian tersebut diketahui bahwa Metode Rough Set dapat digunakan untuk menangani jumlah fitur yang banyak dan mengurangi noise. Sama halnya dengan kedua penelitian yang telah dilakukan oleh (Elshazly , 2012) dan (Reddy, 2011) pada penelitian ini metode Rough Set digunakan untuk melakukan proses klasifikasi kompetensi jabatan dari PNS, yang memiliki multi (banyak) atribut, yaitu Kompetensi Inti, Kompetensi Manajerial dan Kompetensi Teknis-Pengetahuan (disingkat Kompetensi Teknis). Masing-masing kompetensi memiliki beberapa sub atribut dengan level kompetensi mulai dari level 1 sampai dengan level 5. Metode Multi Rough Set digunakan dalam penentuan klasifikasi kompetensi jabatan bagi PNS yang belum diketahui kompetensinya. Metode Rough Set dapat digunakan untuk menyeleksi sejumlah rule yang telah direduksi untuk mendapatkan rule yang lebih sedikit, dengan tetap menjaga kualitas performa klasifikasi dari sebelum dilakukan proses seleksi dan 
mempermudah dalam pengambilan keputusan. Berdasarkan keputusan dari rule yang dihasilkan oleh tiap kelompok kompetensi, maka hasil akhir keputusan diperoleh dengan menggunakan fuzzy rules set yang disebut proses fuzzifikasi.

Pada penelitian ini, data yang digunakan adalah data kompetensi Pegawai Negeri Sipil (PNS) pada Kantor Kementerian Agama Kabupaten Jember, yang menduduki Jabatan Fungsional Umum (JFU) sejumlah 59 orang. Kompetensi Jabatan yang akan digunakan sebagai atribut dalam proses klasifikasi kompetensi menggunakan Metode Multi Rough Set terdiri dari 3 (tiga) kompetensi yaitu : Kompetensi Inti (KI), Kompetensi Manajerial (KM) dan Kompetensi Teknis-Pengetahuan (TP).

\section{METODE PENELITIAN}

\subsection{TEORI ROUGH SET}

Sebuah teknik data mining berbasis matematika yang dikembangkan oleh Pawlack disebut dengan Teori Rough Set dapat lebih efisien digunakan untuk menangani berbagai masalah seperti ketidakpastian, ketidaktelitian dan ketidakjelasan pada berbagai bidang, sebagai contoh salah satunya dalam bidang analisis pengambilan keputusan.

Pada teori ini, sebuat set data direpresentasikan menjadi dua bagian yaitu yang pertama adalah Information Systems (IS) merupakan sebuah tabel pasangan $\mathrm{IS}=\{\mathrm{U}, \mathrm{A}\}$, dimana $\mathrm{U}=\{\mathrm{K} 1$, $\mathrm{K} 2, \ldots, \mathrm{Km}\}$ dan $\mathrm{A}=\{\mathrm{L} 1, \mathrm{~L} 2, \ldots, \mathrm{Ln}\}$ merupakan sekumpulan obyek dan atribut kondisi secara berurutan, yang kedua adalah Decision Systems (DS) dinotasikan dalam $\mathrm{DS}=\{\mathrm{U},\{\mathrm{A}, \mathrm{D}\})$. Dalam sebuah Decision System (DS) akan merepresentasikan semua pengetahuan yang nantinya akan membentuk rules/model. Sebuah tabel keputusan berisi informasi dari sebuah set obyek, yang terdiri dari sejumlah atribut kelas keputusan, dimana akan menghasilkan perkiraan klasifikasi.

Pada penelitian ini algoritma yang berfungsi untuk membangkitkan rule yaitu dengan menggunakan Algoritma Variable Consistency Dominance-based Learning Example Module (VCDomLEM), dimana metode ini disebut Single Rough Set.

\subsection{MULTI ROUGH SET}

\section{A. Pembagian Tabel Sistem Informasi Keputusan}

Metode Multi Rough Set didasarkan pada pendekatan Teori Rough Set, akan tetapi membagi set data sebagai obyek penelitian menjadi bebeberapa kelompok kategori yang di dalamnya memiliki beberapa atribut. Penggunaan atribut yang sangat banyak pasti akan mempengaruhi hasil keputusan. Oleh karena itu metode Multi Rough Set ini digunakan untuk meningkatkan hasil akurasi dan kecepatan proses pengambilan keputusan dalam menentukan hasil klasifikasi.
Gambaran tentang pembagian kelompok kategori set obyek data menjadi beberapa tabel Decision Information System (DIS) dapat dilihat pada Gambar 1 yaitu bahwa Sistem Informasi Keputusan, yang terdiri dari $K 1$ atribut sampai dengan $K_{n}$ atribut $\mathrm{U}=\left(\mathrm{K}_{1}, \mathrm{~K}_{2}, \mathrm{~K}_{3}, \ldots \mathrm{K}_{\mathrm{n}}\right), \mathrm{A}=\left\{\mathrm{O}_{1}, \mathrm{O}_{2}, \mathrm{O}_{3}, \ldots \mathrm{O}_{\mathrm{n}}\right\}$ yang didalamnya mengandung atribut keputusan yaitu $\mathrm{D}$. Dari Tabel Keputusan Sistem Informasi dengan atribut yang sangat banyak tersebut kemudian dibagi menjadi beberapa kelompok kecil tabel informasi yang masing-masing mempunyai atribut keputusan yang sama, dimana bagian tabel pertama terdiri dari atribut $\mathrm{U}_{1}=\left\{\mathrm{K}_{1}, \mathrm{~K}_{2}, \mathrm{~K}_{3}, \ldots \mathrm{K}_{\mathrm{x}}\right\}$ dengan Sistem Keputusan disebut dengan DS $=(\mathrm{U} 1,\{\mathrm{~A}, \mathrm{D}\})$, tabel partisi kedua yang terdiri dari atribut $U_{2}=\left\{K_{x+1}, K_{x+2}\right.$, $\left.\mathrm{K}_{\mathrm{x}+3}, \ldots \mathrm{P}_{\mathrm{y}}\right\}$ mempunyai Sistem Keputusan $\mathrm{DS}=\left(\mathrm{U}_{2}\right.$, $\{A, D\})$ sampai dengan tabel ke $m$ yang terdiri dari Un $=\left\{\mathrm{K}_{\mathrm{y}+1}, \mathrm{~K}_{\mathrm{y}+2}, \mathrm{~K}_{\mathrm{y}+3}, \ldots \mathrm{K}_{\mathrm{n}}\right\}$ mempunyai Sistem Keputusan DS $=\left(\mathrm{U}_{\mathrm{n}},\{\mathrm{A}, \mathrm{D}\}\right)$

Masing-masing tabel tersebut akan dikomputasikan dengan Metode Single Rough Set (Original Rough Set) menggunakan algoritma VCDomLEM untuk menghasilkan rule yang akan digunakan dalam proses klasifikasi.

Berikut gambaran algoritma VC-DomLEM :

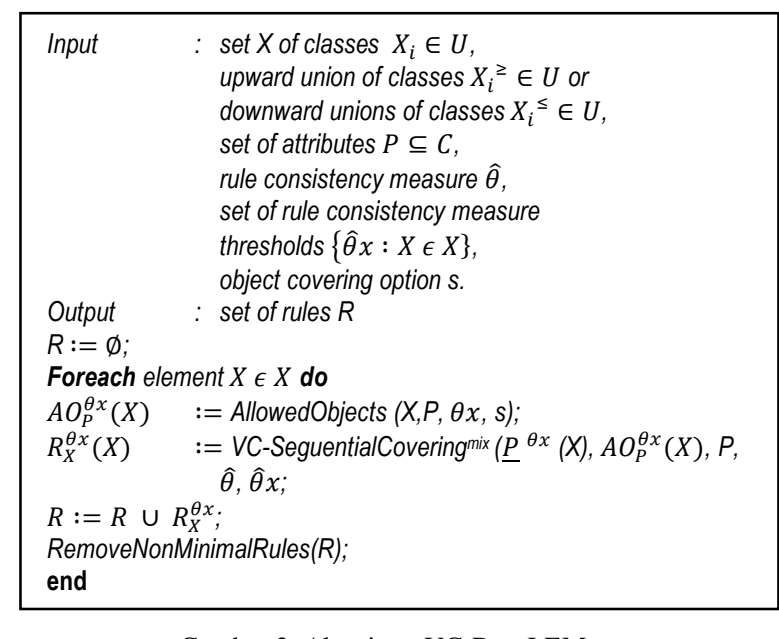

Gambar 2. Algoritma VC-DomLEM

\section{B. Klasifikasi Rough Set}

Langkah-langkah klasifikasi Rough Set pada masing-masing subset data adalah sebagai berikut:

\section{1). Pengumpulan Data}

Tahap pengumpulan data, membagi sebuah set data menjadi 3 kelompok Kompetensi Jabatan yaitu: Kompetensi Inti (KI), Kompetensi Manajerial (KM) dan Kompetensi Teknis/Pengatahuan (KTP) menjadi 2 subset data yaitu sebagai data pelatihan (data training) dan data pengujian (data testing). 


\section{2). Transformasi Data Pelatihan (Data Training) ke Bentuk Kategorikal}

Tahap transformasi ini bertujuan untuk mengubah nilai numerik pada data set menjadi bentuk kategorikal, sehingga dari Tabel Keputusan Tidak Lengkap (Incomplete Decision Table) akan menghasilkan Tabel Hasil Transformasi Data Training ke bentuk kategorikal.

\section{3). Pembentukan Matriks Discernibility}

Matriks Discernibility berisi nilai perbedaan yang dihasilkan dari nilai atribut obyek 1 dengan obyek lainnya.

\begin{tabular}{cccccccc}
\multicolumn{7}{c}{ Tabel 1. Tabel Matriks Discernibility } \\
\hline $\begin{array}{c}\text { N } \\
\mathbf{0}\end{array}$ & \multirow{2}{*}{ Obyek } & $\mathbf{K I}$ & $\mathbf{K I}$ & $\mathbf{K I}$ & $\mathbf{K I}$ & $\mathbf{K I}$ & \multirow{2}{*}{ Dec_KI } \\
\hline 1 & \multirow{2}{*}{ Agustin } & - & KI1 & - & KI2 & KI1 & Class_A \\
2 & Anang & KI & - & - & - & - & Class_B \\
3 & Budi & - & - & KI2 & - & KI2 & Class_D \\
4 & Indah & - & KI2 & - & KI2 & - & Class_C \\
5 & Heri & KI & - & KI1 & - & KI3 & Class_E \\
\hline
\end{tabular}

\section{4). Mencari Reduksi}

Dari Matrik Discernibility tersebut di atas akan menghasilkan Fungsi Discernibility yang bertujuan untuk mencari reduct yaitu dengan cara menyeleksi atribut minimal (interesting attribute) dari sekumpulan atribut kondisi dengan menggunakan Prime Implicant fungsi Boolean. Hasilnya adalah sebagai berikut:

Obyek $1=\mathrm{KI} 1 \Lambda \mathrm{KI} 2(\mathrm{KI} 1 \mathrm{~V} \mathrm{KI} 3)$

$$
=(\mathrm{KI} 1 \Lambda \mathrm{KI} 2 \Lambda \mathrm{KI} 3) \text {, }
$$

begitu juga dengan obyek yang lainnya, dilakukan proses yang sama, sehingga dihasilkan Tabel Fungsi Discernibility untuk menghasilkan Reduct, sebagai berikut:

\begin{tabular}{cc}
\hline \multicolumn{2}{c}{ Tabel 2. Tabel Fungsi Discernibility } \\
\hline No & Fungsi Discernibility \\
\hline 1 & $\mathrm{KI} 1 \Lambda \mathrm{KI} 2 \Lambda \mathrm{KI} 3$ \\
2 & $\mathrm{KI} 1 \Lambda \mathrm{KI} 3$ \\
\hline 3 & $\mathrm{KI} 2 \Lambda \mathrm{KI} 3$ \\
4 & $\mathrm{~K} 2$ \\
5 & $\mathrm{KI} 1 \Lambda \mathrm{KI} 2 \Lambda \mathrm{KI} 3$ \\
\hline Hasil Reduksi & $\mathrm{KI} 1 \Lambda$ KI2 $\Lambda$ KI3 \\
\hline
\end{tabular}

Karena Obyek 1 dan Obyek 5 menghasilkan Fungsi Discernibility yang sama maka dapat dihapus salah satunya.

\section{5). Menghasilkan Model / Rules}

Model atau rules diperoleh dari Tabel Fungsi Discernibility yaitu sebagai berikut:

\begin{tabular}{|c|c|c|}
\hline No & $\begin{array}{c}\text { Fungsi } \\
\text { Discernibility }\end{array}$ & Rules \\
\hline \multirow[t]{2}{*}{1} & $\begin{array}{c}\mathrm{KI} 1 \Lambda \mathrm{KI} 2 \Lambda \mathrm{KI} 3= \\
\{\mathrm{KI} 1, \mathrm{KI} 2, \mathrm{KI} 3\}\end{array}$ & $\begin{array}{c}\text { Jika }((\mathrm{KI} 1=\ldots) \text { dan } \\
(\mathrm{KI} 2=\ldots . .) \text { dan }(\mathrm{KI} 3=\ldots)) \\
\text { Maka Dec_KI }= \\
\text { Class_A }\end{array}$ \\
\hline & $\underset{\mathrm{KI} 1}{\Lambda \mathrm{KI} 3}=\{\mathrm{KI} 1$, & $\begin{array}{c}\text { Jika }((\mathrm{KI} 1=) \text { dan } \\
(\mathrm{KI} 3=\ldots)) \text { Maka Dec_KI } \\
=\text { Class_B }\end{array}$ \\
\hline 3 & $\begin{array}{c}\mathrm{KI} 2 \wedge \mathrm{KI} 3=\{\mathrm{KI} 2, \\
\mathrm{KI} 3\}\end{array}$ & $\begin{array}{c}\text { Jika }((\mathrm{KI} 2=\ldots . .) \text { dan } \\
(\mathrm{KI} 3=\ldots)) \text { Maka Dec_KI } \\
=\text { Class_D }\end{array}$ \\
\hline 4 & $\mathrm{~K} 2=\{\mathrm{KI} 2\}$ & $\begin{array}{c}\text { Jika }(\mathrm{KI} 2=\ldots . .) \text { Maka } \\
\text { Dec_KI }=\mathrm{C}\end{array}$ \\
\hline
\end{tabular}

Model/Rules yang dihasilkan dari masingmasing subset data pelatihan (data training), kemudian akan digunakan dalam Proses Klasifikasi Kompetensi Jabatan yaitu pada Data Pengujian (Data Testing).

\section{Fuzzifikasi}

Hasil klasifikasi pada masing-masing subset data pengujian, akan dilakukan proses fuzzifikasi untuk menghasilkan Hasil Akhir Klasifikasi yang akan digunakan sebagai penentu pengambilan keputusan kompetensi jabatan pegawai.

Berikut gambarannya:

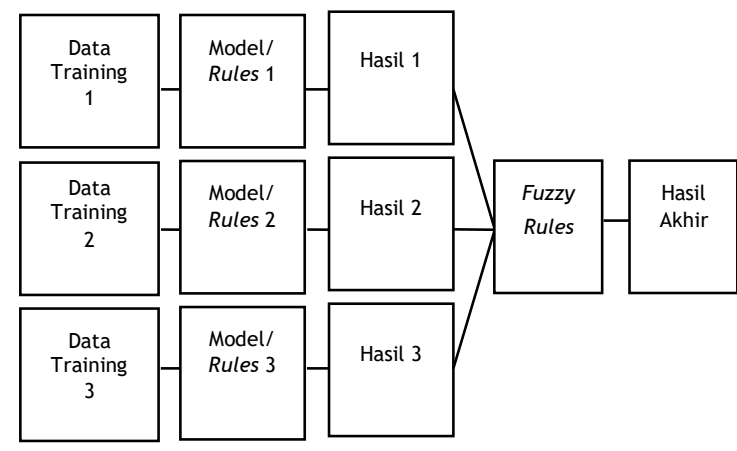

Gambar 3. Proses penentuan hasil akhir klasifikasi dalam Penentuan Kompetensi dan Kelas Jabatan

Data input pada proses fuzzifikasi ini adalah nilai rata-rata dari hasil klasifikasi pada masingmasing kelompok tabel partisi yang telah diperoleh seperti pada gambar 1 . Kemudian nilai rata-rata tersebut akan diuji menggunakan aturan fuzzy sehingga menghasilkan keputusan akhir. Berdasarkan input dan output yang terpilih, menghasilkan 5 buah fungsi anggota, yang ditunjukkan pada grafik berikut ini yaitu Kelas A, Kelas B, Kelas C, Kelas D dan Kelas E :

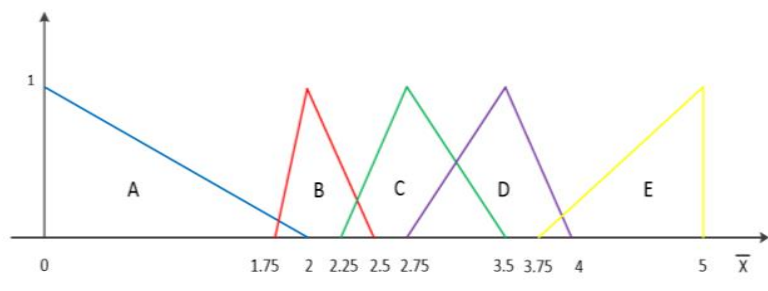

Gambar 4. Fuzzy Membership Function 
Rumus Fuzzy Membership Function:

$$
\begin{aligned}
& \text { Class_A } A(\bar{x})=\left\{\begin{array}{cr}
1 & , \bar{x} \leq 0 \\
\frac{2-\bar{x}}{2-0} & , 0<\bar{x}<2 \\
0, & , 2<\bar{x}
\end{array}\right\} \\
& \text { Class }_{-} B(\bar{x})=\left\{\begin{array}{cr}
0 & , \bar{x} \leq 1.75 \\
\bar{x}-1.75 & , 1.75 \leq \bar{x} \leq 2 \\
2-1.75 & , 2 \leq \bar{x} \leq 2.5 \\
\frac{2.5-\bar{x}}{2.5-2} & , 2.5<\bar{x} \\
0 & , \bar{x} \leq 2.25
\end{array}\right\}
\end{aligned}
$$

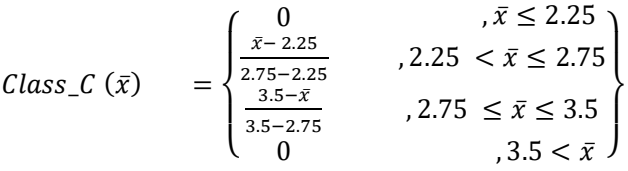

$$
\begin{aligned}
& \text { Class_D }_{-}(\bar{x})=\left\{\begin{array}{cr}
0 & , \bar{x} \leq 3.5 \\
\frac{\bar{x}-2.5}{3.5-2.5} & , 2.5<\bar{x} \leq 3.5 \\
\frac{4-\bar{x}}{4-3.5} & , 3.5 \leq \bar{x} \leq 4 \\
0 & , 4<\bar{x}
\end{array}\right\} \\
& \text { Class_E }_{-}(\bar{x})=\left\{\begin{array}{cr}
0 & , \bar{x} \leq 3.75 \\
\frac{5-\bar{x}}{5-3.75} & , 3.75<\bar{x}<5 \\
1 & , 5 \leq \bar{x}
\end{array}\right\}
\end{aligned}
$$

\section{Pembahasan dan Hasil}

Pada penelitian ini, untuk mencapai tujuan penelitian, bahwa Metode Rough Set dapat digunakan untuk mengklasifikasikan kompetensi jabatan pada Pegawai Negeri Sipil dalam Jabatan Fungsional Umum yang bertujuan untuk menentukan kelas dan nama JFU Pegawai Negeri Sipil (PNS), peneliti mengambil data nilai kompetensi pada Kantor Kementerian Agama Kabupaten Jember yang selanjutnya akan digunakan sebagai atribut dalam penentuan klasifikasi kompetensi jabatan, dimana atribut yang digunakan adalah sejumlah 81 atribut kompetensi yang selanjutnya digunakan sebagai input yang dimiliki 59 orang PNS dalam JFU, terbagi menjadi 5 kelas bidang penempatan yaitu Kelas A (Bidang Sekretaris Jenderal/Sekjen), Kelas B (Bidang Haji), Kelas C (Bidang Penais), Kelas D (Bidang Pendidikan Islam/Pendis), Kelas E (Bidang Non Islam) dan selanjutnya disebut sebagai output. Jumlah obyek data set pada masing-masing kelas bidang penempatan jumlahnya tidak sama yaitu pada Kelas A 19\%, Kelas B 11\%, Kelas C 53\%, Kelas D 15\% dan Kelas E 2\%.

\section{A. Tahap Pelatihan (Training Phase)}

\section{1) Pengelompokkan Atribut}

Pada Tahap Pelatihan ini Kompetensi Jabatan sejumlah 81 kompetensi yang selanjutnya disebut atribut $\mathrm{K}\left(\mathrm{K}_{1}, \mathrm{~K}_{2}, \mathrm{~K}_{3}, \ldots, \mathrm{K}_{81}\right)$ dikelompokkan menjadi 3 (tiga) kelompok kategori kompetensi yaitu Kompetensi Inti (KI) terdiri dari 5 atribut yaitu $\left(\mathrm{K}_{1}\right.$, $\mathrm{K}_{2}, \mathrm{~K}_{3}, \mathrm{~K}_{4}, \mathrm{~K}_{5}$ ), Kompetensi Manajerial (KM) terdiri dari 16 atribut yaitu $\left(\mathrm{K}_{6}, \mathrm{~K}_{7}, \mathrm{~K}_{8}, \ldots \mathrm{K}_{21}\right)$ dan Kompetensi Teknis/Pengetahuan (KTP) terdiri dari 60 atribut yaitu $\left(\mathrm{K}_{22}, \mathrm{~K}_{23}, \mathrm{~K}_{24}, \ldots \mathrm{K}_{81}\right)$.

Klasifikasi penentuan kompetensi jabatan PNS dalam Jabatan Fungsional Umum (JFU) dibagi menjadi 5 kelas yang selanjutnya disebut dengan Atribut Keputusan D (Decision Attribute) yaitu : Kelas A (Bidang Sekretaris Jenderal/Sekjen), Kelas B (Bidang Haji), Kelas C (Bidang Penais), Kelas D (Bidang Pendidikan Islam/Pendis), Kelas E (Bidang Non Islam).

\section{2) Pembentukan Rule (Rule Induction)}

Pada penelitian ini 59 obyek data sampel, 20\% digunakan sebagai data testing untuk tahap pelatihan dengan metode 5-Fold Cross Validation, sehingga akan terpilih rule terbaik dengan tingkat akurasi tertinggi, yang dapat digunakan pada data testing untuk tahap pengujian yaitu $80 \%$ obyek data sampel.

Obyek penelitian yang digunakan adalah PNS dalam Jabatan Fungsional Umum (JFU) sejumlah 59 orang, dengan prosentase $20 \%$ digunakan sebagai data testing untuk tahap pelatihan dengan metode 5Fold Cross Validation, sehingga akan terpilih rule terbaik dengan tingkat akurasi tertinggi, yang dapat digunakan pada data testing untuk tahap pengujian yaitu $80 \%$ obyek. Selanjutnya akan dilakukan proses komputasi dengan metode Rough Set menggunakan algoritma VC-DomLEM, dimana dari proses tersebut menghasilkan aturan/rule dari masing-masing kelompok kompetensi sesuai bidang penempatannya, yaitu: kelompok Kompetensi Inti menghasilkan 2 rule, kelompok Kompetensi Manajerial menghasilkan 8 rule, dan kelompok Kompetensi Teknis/Pengetahuan menghasilkan 3 rule. Hasil eksperimen ditunjukkan pada Tabel 4 berikut ini:

\begin{tabular}{cccc} 
Tabel 4. Table Experimental Result dalam Nilai Nominal \\
\hline Object & K_Inti & $\begin{array}{c}\text { K_Manaje } \\
\text {-rial }\end{array}$ & $\begin{array}{c}\text { K_Teknis } \\
\text { Pengetahuan }\end{array}$ \\
& & & \\
\hline 1 & Class_A & Class_C & Class_A \\
2 & Class_A & Class_C & Class_A \\
3 & Class_A & Class_A & Class_A \\
4 & Class_A & Class_C & Class_A \\
5 & Class_A & Class_C & Class_A \\
6 & Class_A & Class_A & Class_B \\
7 & Class_B & Class_B & Class_B \\
8 & Class_A & Class_C & Class_B \\
9 & Class_A & Class_C & Class_C \\
10 & Class_A & Class_C & Class_C \\
11 & Class_A & Class_C & Class_C \\
12 & Class_A & Class_C & Class_C \\
13 & Class_A & Class_C & Class_C \\
14 & Class_A & Class_C & Class_C \\
15 & Class_A & Class_C & Class_C \\
16 & Class_A & Class_C & Class_C \\
17 & Class_A & Class_C & Class_C \\
18 & Class_A & Class_C & Class_C \\
19 & Class_A & Class_A & Class_C \\
20 & Class_A & Class_C & Class_C \\
21 & Class_A & Class_C & Class_C \\
22 & Class_A & Class_C & Class_B \\
23 & Class_A & Class_C & Class_B \\
24 & Class_A & Class_C & Class_B \\
25 & Class_A & Class_C & Class_B \\
26 & Class_B $B$ & Class_C & Class_C \\
\hline & & &
\end{tabular}

\section{B. Tahap Pengujian}

Pada Tahap Pengujian dilakukan menggunakan 10-Fold Cross Validation pada masing-masing kelompok Kompetensi Inti, Kompetensi Manajerial dan Kompetensi Teknis/Pengetahuan. 


\section{1). Diskretisasi}

Hasil dari Tabel Eksperimental dalam Nilai Nominal akan dilakukan proses diskretisasi menjadi Nilai Numerik, berdasarkan Tabel Diskretisasi berikut ini:

\begin{tabular}{cc} 
Tabel 5. Diskretisasi & \\
\hline Decision Attribute & Value \\
\hline Class_A $A$ & 1 \\
Class_B & 2 \\
Class_C & 3 \\
Class_D & 4 \\
Class_E & 5 \\
Unclassified & 0 \\
\hline
\end{tabular}

Hasil Tabel Eksperimental dalam Nilai Numerik yang selanjutnya akan digunakan sebagai input pada proses Fuzzifikasi, ditunjukkan pada Tabel 6 adalah sebagai berikut:

\begin{tabular}{|c|c|c|c|c|c|}
\hline $\mathrm{K}_{\text {Inti }}$ & $\begin{array}{c}\text { K_Ma- } \\
\text { najerial }\end{array}$ & $\begin{array}{c}\text { K_ } \\
\text { Teknis } \\
\text { Penget } \\
\text { a-huan } \\
\end{array}$ & Mean & $\begin{array}{c}\text { Fuzzy } \\
\text { Decision }\end{array}$ & $\begin{array}{c}\text { Target } \\
\text { Decision }\end{array}$ \\
\hline 1 & 3 & 1 & 1.667 & Class_A & Class_A \\
\hline 1 & 3 & 1 & 1.667 & Class_A & Class_A \\
\hline 1 & 1 & 1 & 1.000 & Class_A & Class_A \\
\hline 1 & 3 & 1 & 1.667 & Class_A & Class_A \\
\hline 1 & 3 & 1 & 1.667 & Class_A & Class_A \\
\hline 1 & 1 & 2 & 1.333 & Class_A & Class_B \\
\hline 2 & 2 & 2 & 2.000 & Class_B & Class_B \\
\hline 1 & 3 & 2 & 2.000 & Class_B & Class_B \\
\hline 1 & 3 & 3 & 2.333 & Class_C & Class_C \\
\hline 1 & 3 & 3 & 2.333 & Class_C & Class_C \\
\hline 1 & 3 & 3 & 2.333 & Class_C & Class_C \\
\hline 1 & 3 & 3 & 2.333 & Class_C & Class_C \\
\hline 1 & 3 & 3 & 2.333 & Class_C & Class_C \\
\hline 1 & 3 & 3 & 2.333 & Class_C & Class_C \\
\hline 1 & 3 & 3 & 2.333 & Class_C & Class_C \\
\hline 1 & 3 & 3 & 2.333 & Class_C & Class_C \\
\hline 1 & 3 & 3 & 2.333 & Class_C & Class_C \\
\hline 1 & 3 & 3 & 2.333 & Class_C & Class_C \\
\hline 1 & 1 & 3 & 1.667 & Class_A & Class_C \\
\hline 1 & 3 & 3 & 2.333 & Class_C & Class_C \\
\hline 1 & 3 & 3 & 2.333 & Class_C & Class_C \\
\hline 1 & 3 & 2 & 2.000 & Class_B & Class_D \\
\hline 1 & 3 & 2 & 2.000 & Class_B & Class_D \\
\hline 1 & 3 & 2 & 2.000 & Class_B & Class_D \\
\hline 1 & 3 & 2 & 2.000 & Class_B & Class_D \\
\hline 2 & 3 & 3 & 2.667 & Class_C & Class_E \\
\hline
\end{tabular}

\section{2). Fuzzifikasi}

Hasil akhir yang diperoleh berdasarkan input nilai rata-rata dari nilai numerik hasil diskretisasi pada Tabel Hasil Eksperimental dalam Nilai Nominal yang akan dihasilkan keputusan akhir pada proses klasifikasi. Perlu diperhatikan bahwa nilai 0 (unclassified) tidak akan mempengaruhi proses perhitungan nilai rata-rata. Sehingga dari proses fuzzifikasi dihasilkan Hasil Akhir Klasifikasi Kelas A $27 \%$, Kelas B 23\%, Kelas C 50\%, Kelas D 0\% dan Kelas E $0 \%$. Nilai $0 \%$ pada Kelas D dan Kelas E, dapat diartikan bahwa berdasarkan nilai kompetensi jabatan yang ada, tidak ada pegawai yang berkompeten untuk ditempatkan pada Bidang Pendidikan Islam (Pendis) dan Bidang Non Islam. Pada Kelas E atau Bidang Non Islam pada kondisi real memang memiliki jumlah pegawai yang sangat minimal sehingga penempatan pegawai diambilkan dari pegawai yang memiliki kompetensi umum pada bidang lain, hanya bedanya pada agama yang dianut oleh pegawai tersebut, yaitu agama Kristen dan Katholik.

\section{Tahap Evaluasi}

Confusion matrix dan Reciever Operating Curve (ROC) digunakan pada tahap evaluasi untuk menentukan tingkat akurasi dan rata-rata error dari hasil klasifikasi pada metode Single Rough Set dan Multi Rough Set. Nilai rata-rata error untuk hasil yang tidak terklasifikasi (unclassified) berdasarkan metode Single Rough Set semula sebesar 28,57\% meningkat menjadi 0\% dengan menggunakan metode Multi Rough Set. Sedangkan tingkat akurasi metode Single Rough Set meningkat dari 38,78\% menjadi 57,14\% dengan metode Multi Rough Set.

Grafik $R O C$ pada gambar 5 menunjukkan bahwa luas daerah di bawah kurva (Area Under Curve / AUC) sebesar 0,866, yang berarti bahwa metode Multi Rough Set sebagai metode klasifikasi (Good Classifier) yang baik untuk menentukan hasil keputusan penentuan klasifikasi kompetensi pegawai dalam Jabatan Fungsional Umum (JFU).

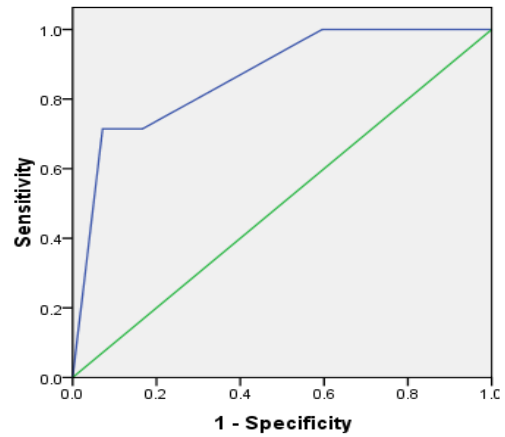

Gambar 4.8 Kurva ROC dari Hasil Klasifikasi Metode Multi Rough Set

\section{Kesimpulan}

Berdasarkan hasil penelitian tersebut di atas dapat disimpulkan bahwa Metode Multi Rough Set sebagai metode klasifikasi yang baik untuk dapat digunakan pada Kasus Klasifikasi, seperti pada penelitian ini adalah Klasifikasi Kompetensi Jabatan Pegawai Negeri Sipil dalam Jabatan Fungsional Umum (JFU) dalam menentukan kompetensi dan kelas jabatan sehingga dapat mengurangi hasil unclassified (tidak terklasifikasi), dan akan memperoleh tingkat akurasi yang lebih tinggi dibandingkan dengan Metode Single Rough Set. Pada penelitian selanjutnya, Metode Multi Rough Set dapat dibandingkan atau digabungkan dengan metode klasifikasi lainnya seperti naive bayes, back propagation dan lain sebagainya, sehingga mungkin akan diperoleh hasil akurasi yang lebih baik dan 
tingkat kesalahan kelas yang tidak terklasifikasi (unclassified) dapat dikurangi.

\section{SUMBER RUJUKAN}

A. ROJARATH, W. S. a. C. P.-i., 2016. Improved ensemble learning for classification techniques based on majority voting. Beijing, s.n., pp. 107-110.

ANTONIUS RAHMAT C., Y. L., 2015. Implementation of labeling crowdsourced web-based system using weighted majority voting method (Implementasi system crowdsourced labelling berbasis web dengan metode weighted majority voting). ULTIMA Infosys Information System Journal (Ultima Infosys Jurnal Sistem Informasi), December, VI (2), pp. 76-82.

ASHARI, E. T., 2011. Regulation of the Head of Human Resources Number 13 Year 2011 about Guidelines for preparation of job competency (Peraturan Kepala Badan Kepegawaian Nomor 13 Tahun 2011 tentang Pedoman Penyusunan Kompetensi Jabatan). Jakarta: National Civil Service Agency (Badan Kepegawaian Negara).

CARTER, J., 2016. ROC-in along: Evaluation and interpretation of receiver operating curves. Surgery, Elsevier, June, Volume 159, p. 6.

DING, S. D. a. A., 2011. A method for data classification based on Rough Sets Theory. Yichang, 2011 International Conference on Electrical and Control Engineering, pp. 42614264.

Forum, E. W., 2016. https://reports.weforum.org/. [Online]

Available at: https://reports.weforum.org [Diakses 30 Maret 2016].

HAN, J., 2012. Data mining : Concepts and Techniques. 3rd ed. penyunt. 225 Wyman Street, Waltham, MA 02451: Morgan Kaufmann Publishers.

James, G., $2017 . \quad$ [Online] Available web.stanford.edu/ hastie/THESES

N. Z. FANANI, U. D. R. S. S. a. M. H. P., 2016. Multi Attribute Decision Making Model Using Multi Rough Set: Case Study Classi fication of Anger Intensity of Javanese Woman. Budapest, 2016 IEEE International Conference on Computational Intelligence and Virtual Environments for Measurement Systems and Applications (CIVEMSA), pp. 15.

NUR SYAM, P. D. H. M., 2015. Dictionary of Job Competency (Kamus Kompetensi Jabatan). Jakarta: The General Secretariat of the Ministry of Religious Affairs of the Indonesian Republic (Sekretariat Jenderal Kementerian Agama Republik Indonesia).
S. GRECO, B. M. a. R. S., 2001. Rough sets theory for multicriteria decision analysis. European Journal of Operational Research, February, 129 no.1(1), p. 1-47.

SANTOSA, B., 2007. Data Mining, Data Utilization Techniques for Business Purposes, Techniques \& Applications (Data Mining, Teknik Pemanfaatan Data untuk Keperluan Bisnis, Teknik \& Aplikasinya). Yogyakarta: Graha Ilmu.

SLEZAKk, D., 2007. Rough Sets and Few-ObjectsMany-Attributes Problem: The Case Study of Analysis of Gene Expression Data Sets. Jeju City, s.n., pp. pp. 437-442.

SPENCER, L. M. a. S. M. S., 1993. Competence Work: Model for Superior Performance, s.l.: John Wiley and Sons. Inc.

SURAZ, Z., 2004. An Introduction to Rough Set Theory and Its Applications A Tutorial, Cairo, Egypt: ICENCO.

VENKATESWARA REDDY E., S. G. V. R. E. S. a. S. S. S., 2011. Rough Set Anlaysis for Uncertain Data Classification. India, s.n., pp. $22-29$.

ZURNALI, C., 2009. Learning Organization, Competency, Organizational Commitment, dan Customer Orientation : Knowledge Worker - Kerangka Riset Manajemen Sumberdaya Manusia di Masa Depan. Bandung: Unpad Press.

HARI PURNOMO SRI KUSUMADEWI, Aplikasi Logika Fuzzy untuk Pendukung Keputusan, 2nd ed. Yogyakarta, Indonesia: Graha Ilmu, 2010.

J. CARTER, "ROC-in along: evaluation and interpretation of receiver operating curves," Surgery, Elsevier, vol. 159, p. 6, June 2016. 
Halaman ini sengaja dikosongkan 